\title{
ADVANCED USAGE OF INERTIA TEST STAND - MEASUREMENT OF THE GEARBOX NO-LOAD LOSSES
}

\section{GABRIELA ACHTENOVÁ, JIŘí PAKOSTA}

Czech Technical University in Prague, Technická 4, CZ-166 07, Prague 6, Czech Republic

E-mail: gabriela.achtenova@fs.cvut.cz, jiri.pakosta@fs.cvut.cz

\section{ABSTRACT}

In the laboratories of Czech Technical University in Prague a new inertia test stand was designed and realised. Its main purpose is to test the behavior and endurance of the internal shift mechanisms of passenger car gearboxes. In this paper we present further usage of the test stand, which consists of measurement of gearbox losses. The gearbox on the inertia test stand cannot be loaded; therefore the target is the measurement of losses resulting mainly from splash lubrication and some additional gearbox friction (e.g. friction in shaft sealing, bearing losses). The most typical passenger car mechanical five speed gearbox for transversal position of the drivetrain was chosen for this experiment.

KEYWORDS: PASSENGER CAR GEARBOX, LUBRICATION LOSSES, FRICTION LOSSES

\section{SHRNUTI}

V laboratořích ČVUT v Praze byl navržen a postaven setrvačníkový zkušební stav. Hlavním cílem tohoto stanoviště bylo testovat chování a životnost vnitřního mechanismu řazení prevodovek osobních vozidel. Ve článku je prezentováno další použití setrvačníkového stanoviště pro měření účinnosti. Převodovka v setrvačníkovém stavu není zatížena, proto je možné měřit pouze velikost ztrát vznikajících mazáním a některé další typy ztrát (např. tření v hřídelových těsněních, ztráty v ložiskách). Jako testovací príklad jsme si vybrali nejtypičtější prevodovku osobních vozidel - pětistupňovou mechanickou s ručním řazením pro príčnou zástavbu do vozidla.

\section{KLÍČOVÁ SLOVA: PŘEVODOVKA PRO OSOBNÍ AUTOMOBIL, ZTRÁTY BRODĔNÍM, TŘECÍ ZTRÁTY}

\section{INTRODUCTION}

The main sources for gearbox losses are oil churning, seal friction, and gear mesh and bearing friction [4]. Generally the losses can be split into two groups: load dependent and no-load losses. In the real life of the gearbox the ratio between the proportion of the load dependent and no-load losses on the overall efficiency strongly varies. During low load the churning losses and seal drag contribute to the overall efficiency for about $80 \%$. When the gearbox is highly loaded the proportion between load dependent losses and the oil churning is reversed $(80: 20) ;[1]$.

The load dependent losses depend on the transmitted load through the gearbox, coefficient of friction and the sliding velocity [2]. The main source of load dependent losses is the gearmesh. The determination of gearmesh efficiency is described in the literature especially for the case of helical gears used in automotive gearboxes; [3], [7].

The no-load losses are difficult to predict mathematically. They depend on the form of the gearbox case, on the amount of oil, type of oil - especially its viscosity, temperature, etc.
This task was investigated by the Lyon's Research Center ECAM, which resulted in a series of formulas for accurate prediction of churning losses for automotive transmission geometry [5]. To implement into study the influence of forms and deflectors the work was further elaborated and presented in [6]. In all cases the test setup and proposed equations comprises just one gear pair. Therefore we decided to experimentally investigate the no-load losses of the total passenger car gearbox during different conditions. We investigated the dependence of the losses on the speed of rotation and on the oil temperature. For the experimental measurement we used the test stand which is mainly dedicated for endurance tests of synchronizer clutches. The instrumentation of the test stand however, allows us to expand the usage of this facility to measurements of gearbox no-load losses.

First we will describe the inertia test stand and the tested gearbox. Next we will demonstrate the measured results of drag torque and lost power in the transmission. 


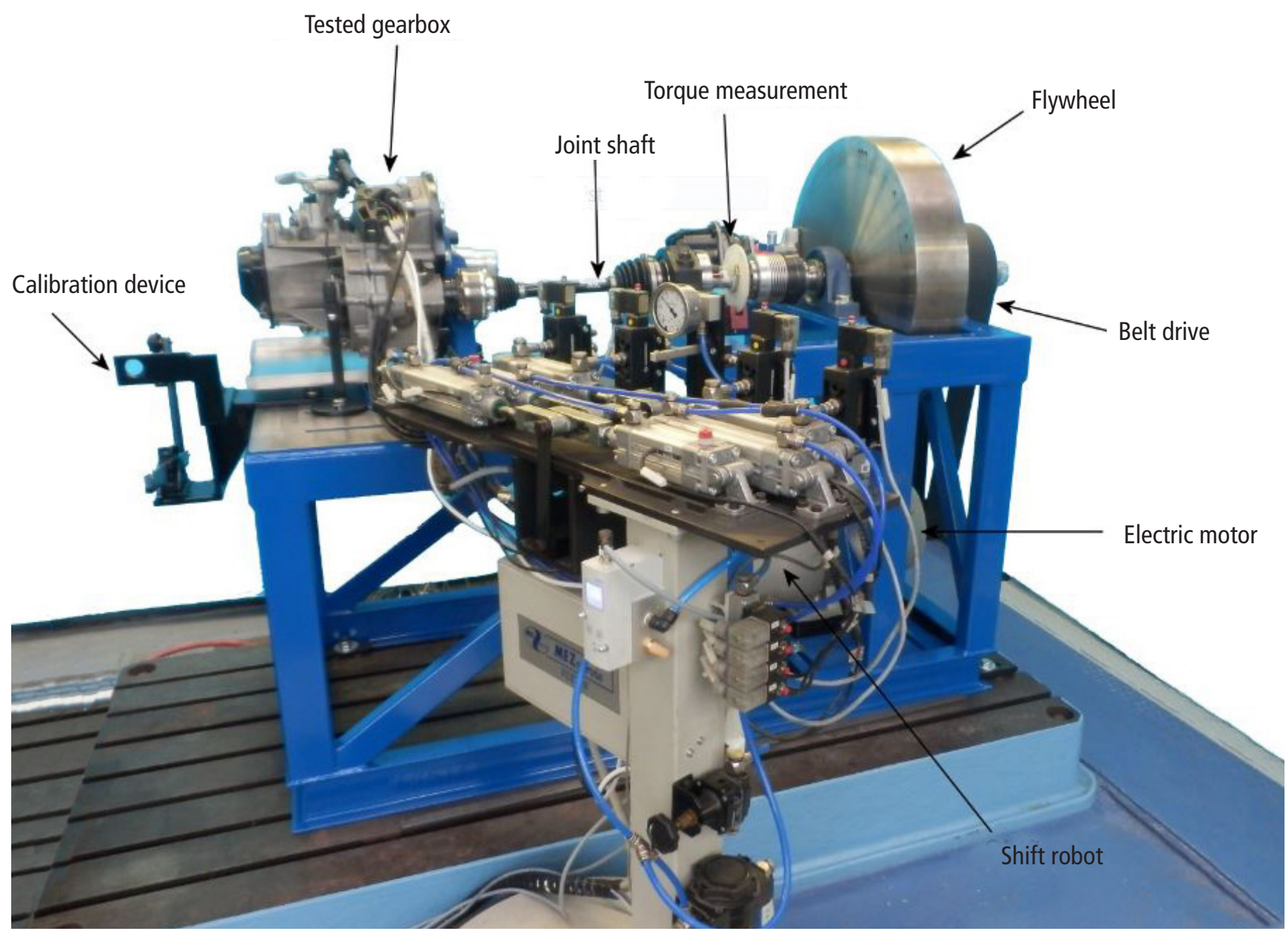

FIGURE 1: Flywheel test stand for endurance and gear-shift mechanisms behaviour tests. For clarification of the whole assembly the protection covers were removed for the taking of the picture.

OBRÁZEK 1: Setrvačníkový stav pro zkoušky životnosti a chování řadicích mechanismů. Pro přehlednost byly pro účel fotografie odejmuty všechny ochranné kryty.

\section{DESCRIPTION OF THE INERTIA TEST STAND}

For the test stand design the main requirement was to keep the design as simple as possible by keeping the similar functional condition as in a real vehicle. Figure 1 shows the test stand (it should be noted that the test stand is equipped with several protection covers. They were removed just for the clarification of the stand arrangement in the Figure). The moment inertia of flywheel of the test stand is $15 \mathrm{~kg} . \mathrm{m} 2$. This value was chosen as optimum between the demand of inertia representing the passenger car, and the demand for low inertia, which can be fast accelerated of decelerated to minimize the technological time for endurance tests. In all cases for the current study, this value of moment of inertia is not important, because all measurement were performed with constant speed of rotation.

The following description covers only the features directly relevant to the measurement of the drag losses. The flywheel is driven by $\mathrm{AC}$ electrical motor controlled by frequency converter.
The normal deceleration is ensured with braking resistances linked to the frequency converter. As emergency brake was chosen the disc brake acting directly on the flywheel, and operated by spring, which is capable to stop the flywheel from $1000 \mathrm{rpm}$ to standstill in $1 \mathrm{~s}$. For the drag torque measurement the speed of the AC motor was tuned to obtain 1000, 2000, 3000,4000 and $5000 \mathrm{rpm}$ on the input shaft of the gearbox. During the measurement the constant speed was kept.

The electric motor drives the axle shaft connected to one central gearwheel of gearbox differential via belt drive. The gearbox is then driven from its output side (the differential has to be blocked). The gearbox clutch housing face is fastened with screws to the stand frame. The easily interchangeable mounting plate is designed to allow gearshift tests of different transmissions. The clutch plate is inserted on the gearbox input shaft, in order to keep the realistic moment of inertia of the gearbox primary part. 


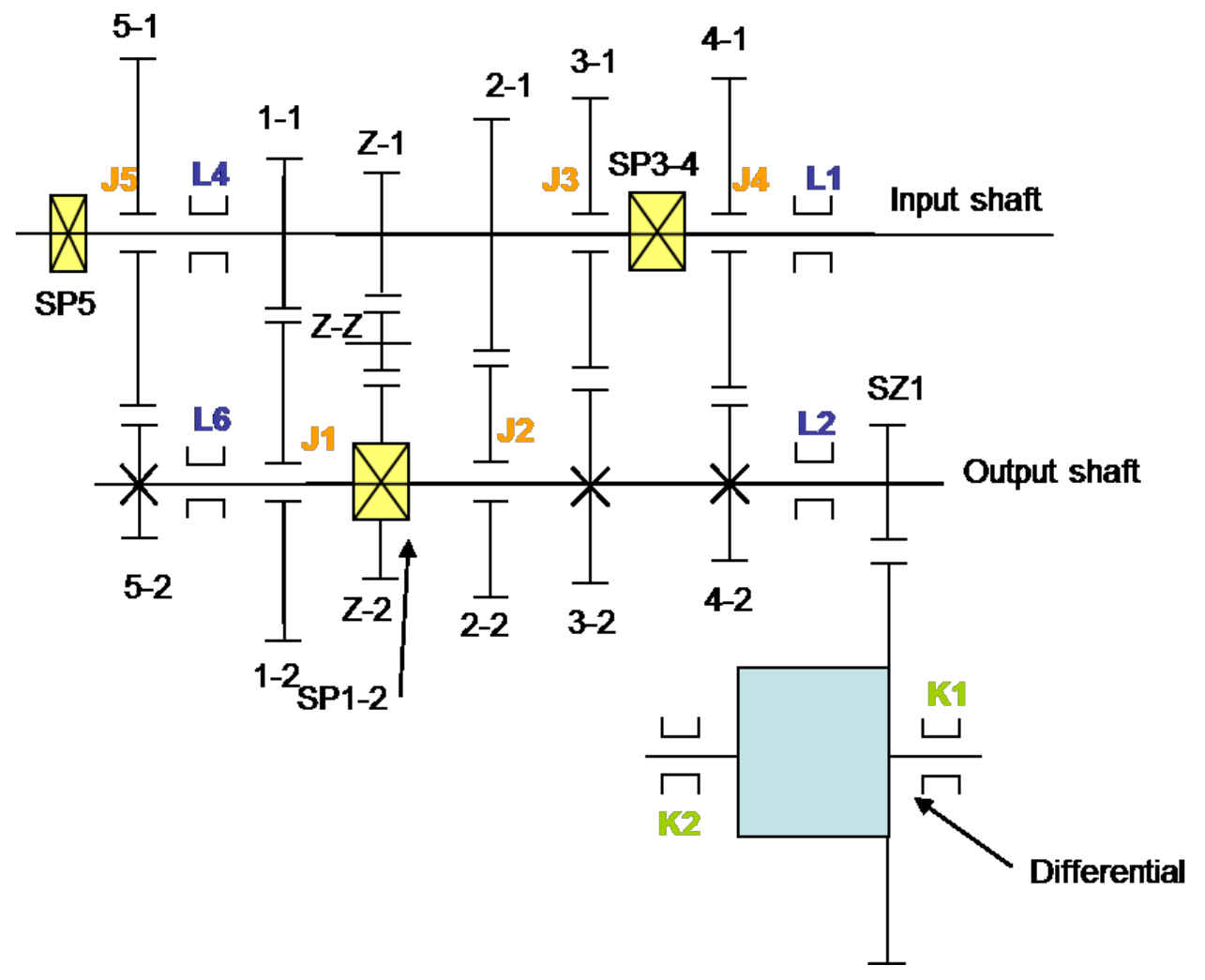

FIGURE 2: Scheme of the tested gearbox

OBRÁZEK 2: Schéma testované převodovky

The flywheel stand is equipped with rotational sensor of the input and output shafts, gearbox temperature, shift force and lift, and output torque measured with help of the telemetric device from ESA Messtechnik. The data acquisition and stand control is programmed with help of Labview software. For the calibration of the torque sensor is prepared the calibration lever. For calibration of the shift force is prepared the lever mechanism, screwed on the test stand frame.

\section{DESCRIPTION OF THE TESTED GEARBOX}

The tested gearbox was the most common automotive gearbox for usage in drivetrain with transversally disposition and front wheel drive. All gears are helical (with exception of reverse with spur gears) and differential. This gearbox is representative for middle class of passenger cars. The gearbox comprises the final drive and front axle differential. The scheme of the gearbox (Figure 2) shows clearly the position of free rotating wheels, synchronizer clutches (SP), and bearings (L). The input and output shaft are mounted on a pair of ball bearing $(L 4, L 6)$ and roller bearing $(L 1, L 2)$. The differential case is mounted on tapered roller bearings $(\mathrm{K} 1, \mathrm{~K} 2)$. The main sealing friction losses come from three radial shaft sealings. One is placed on the input shaft, and remaining two seal the output flanges.

\section{MEASURED DATA - NO-LOAD LOSSES}

The lost power of the gearbox was evaluated for three different temperatures and with regard to the different levels of speed of rotation of input shaft. The torque sensor is placed directly behind the joint shaft; the measured torque - see graphs in Figure 3 - is in fact the drag torque of the gearbox coming from all no-load losses in the gearbox. The main no-load losses are:

- churning losses,

- bearing losses (no-load),

- seal frictional losses,

- gear mesh losses.

In [2] was demonstrated that the no-load gear losses depends mainly on the immersion depth and lubricant viscosity. The oil level in the investigated gearbox reaches approximately $14 \mathrm{~mm}$ under the axis of the output flanges (i.e. under the center-axis of the differential) in the steady state. It means that the differential with the final drive crown wheel, and the gearwheels of the first three forward speeds $\left(1^{\text {st }}, 2^{\text {nd }}\right.$, and $\left.3^{\text {rd }}\right)$ are partially immerged in oil in steady state. The final drive crown wheel is in fact the main wheel which assures the lubricant distribution through the whole gearbox. The final drive and the gear wheels on output shaft are main sources of churning losses. The higher gear is engaged the higher 

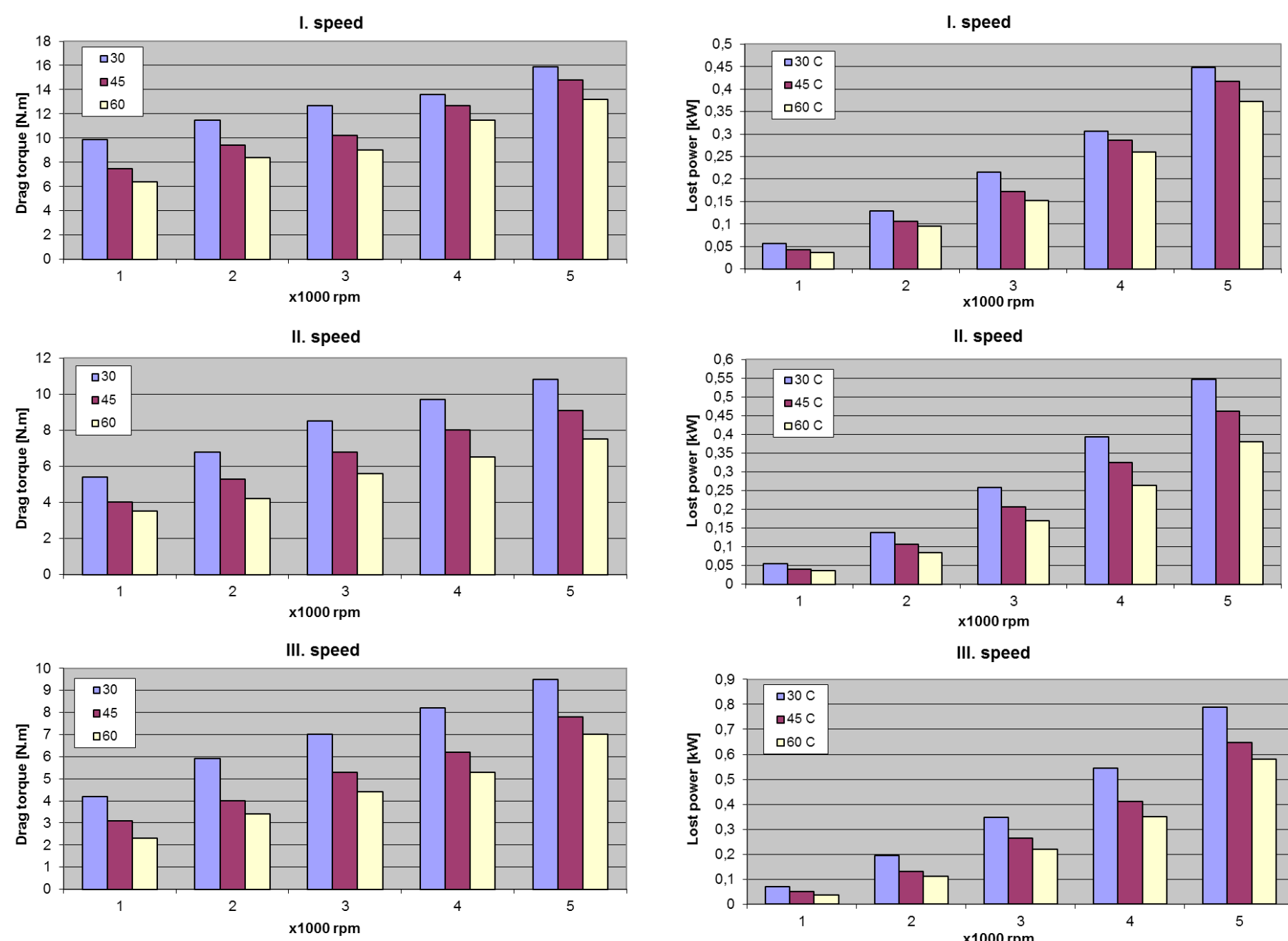

IV. speed
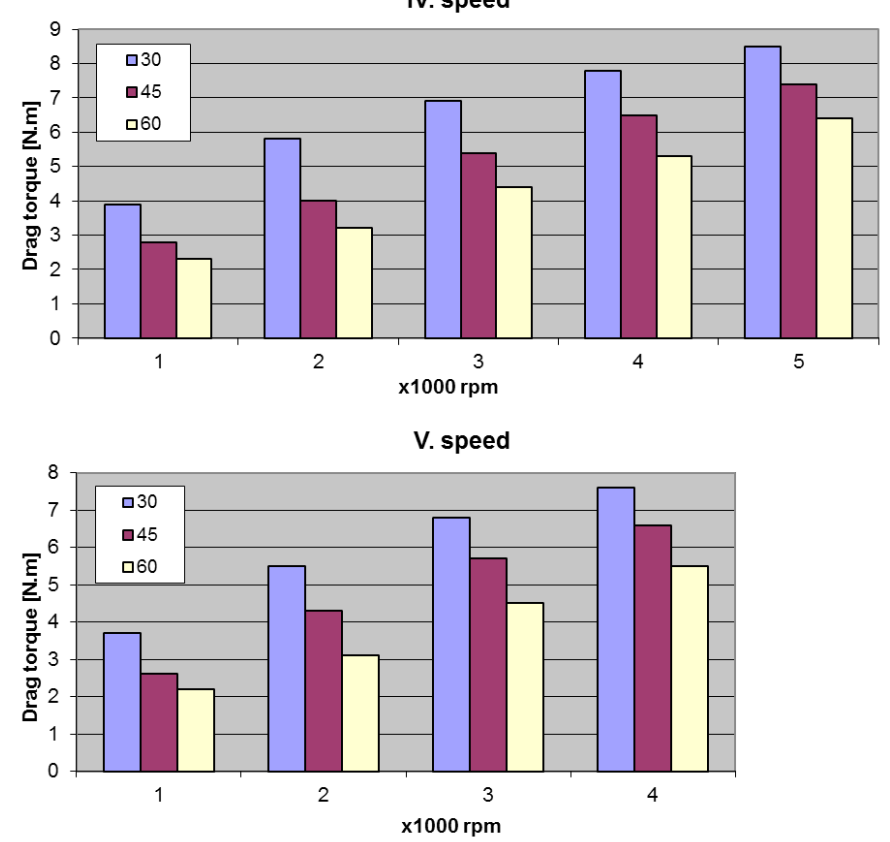

FIGURE 3: Dependence of drag torque on the speed of the gearbox input shaft, shifted speed and temperature of the oil.

OBRÁZZEK 3: Závislost ztrátového momentu na otáčkách vstupního hř́dele převodovky, zařazené rychlosti a teplotě oleje.
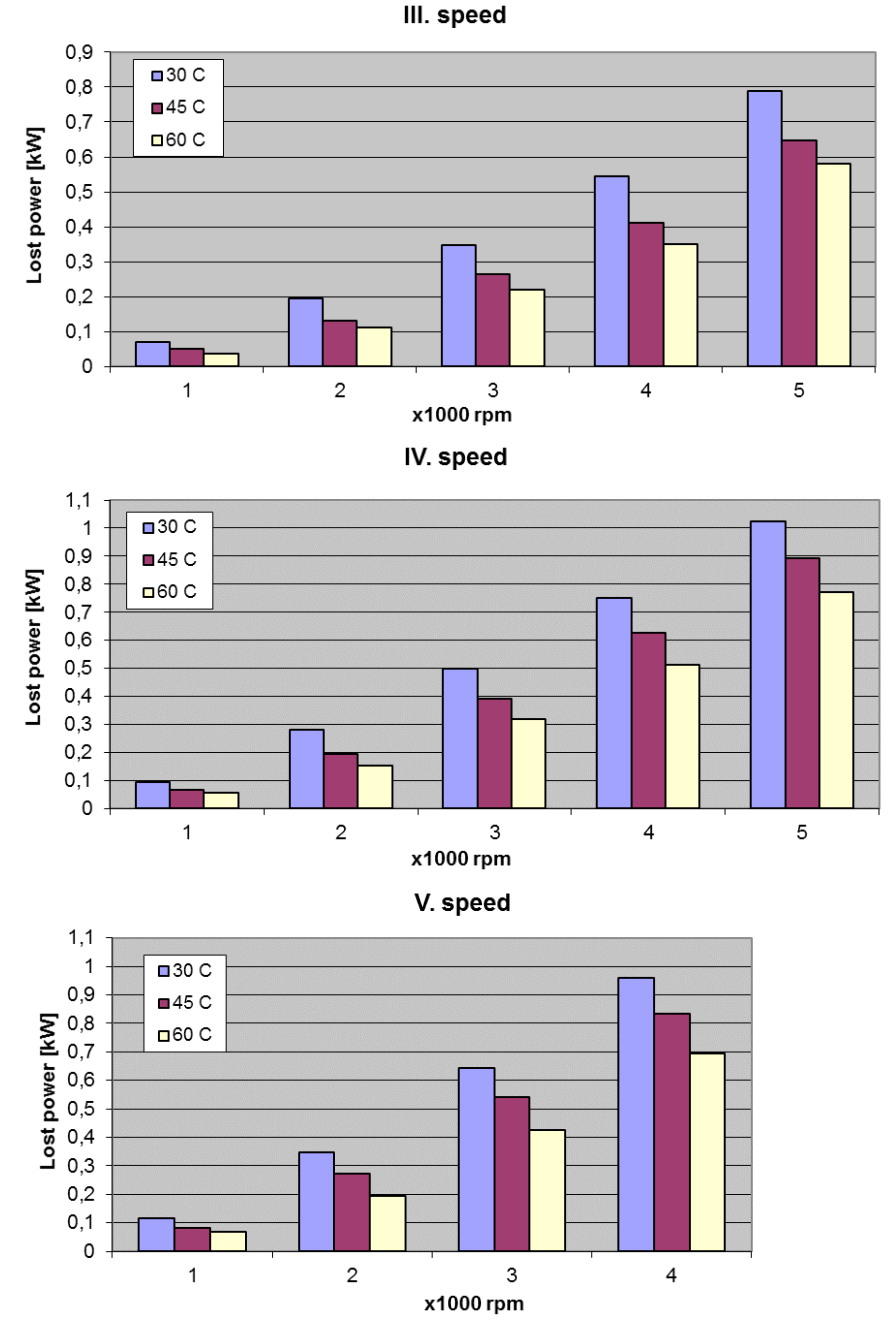

FIGURE 4: Dependence of lost power on the speed of the gearbox input shaft, shifted speed and temperature of the oil.

OBRÁZEK 4: Závislost ztrátového výkonu na otáčkách vstupního hř́dele převodovky, zařazené rychlosti a teplotě oleje. 
speed of rotation of output shaft and differential is achieved, so the higher churning losses are observed. In the following graphs are depicted the results of the no-load lost power in different conditions. The lost power was calculated from the measured drag torque and speed of rotation.

The effect of the no-load losses can be seen from the dependence of the lost power on the input shaft speed in rpm, and also on the shifted speed. The higher shifted speed the lower ratio, it means the higher speed of the crown wheel of final drive (gear pair SZ1 in Figure 2).

Further we can observe logical result, that the lost power is dependent on the oil temperature. With lower temperature the viscosity increases, which obviously mean higher drag torque. The increase of lost power with the increase of speed of rotation is approximately linear. The increase of lost power with decrease of temperature is nonlinear, corresponding to the non-linearity of the dependence viscosity - temperature of the gearbox oil.

The disadvantage of the actual inertia test stand is that the warming of the oil temperature is possible through no-load losses in the gearbox and synchronizer friction only. Without any other energy source 60 degrees $C$ is the maximum achievable temperature of the gearbox.

The actual ratio of the belt drive between the electric motor and the gearbox output joint shaft did not allow the rotation of the gearbox input shaft on $5000 \mathrm{rpm}$ when $5^{\text {th }}$ speed was shifted.

\section{CONCLUSION}

From the experiments we can conclude that the inertia test stand can serve for high precision measurements of no-load losses. In next research we aim to determine the amount of influence in the no-load losses by the following different sources: bearings, churning losses, and sealing. For the continuation of the project we aim to use both the mathematical model and experimental measurement.

\section{ACKNOWLED GEMENTS}

This research has been realized using the support of EU Regional Development Fund in OP R\&D for Innovations (OP VaVpl) and Ministry of Education, Czech Republic, project \# CZ.1.05/2.1.00/03.0125 Acquisition of Technology for Vehicle Center of Sustainable Mobility.

Further this research has been realized with help of the support of Technological Agency, Czech Republic, programme Centres of Competence, project \#TE01020020 Josef Božek Competence Centre for Automotive Industry.

Both supports are gratefully acknowledged.

\section{REFERENCES}

[1] Johnson M.L. (2009). Improving Energy Efficiency through Lubrication, In: Gear Efficiency and Lubrication, Sumitomo Drive Technologies

[2] Höhn B.-R., Michaelis K. and Hinterstoisser M. (2009). Optimization of Gearbox Efficiency. In: Goriva i maziva, Vol. 48, Nr. 4, pp. 441 -480. ISSN 0350-350X

[3] Pedrero J.I., Estrems M. and Fuentes A. (1999). Determination of the Efficiency of Cylindric Gear Sets, In: Proceedings of Congres Mondial des Engrenages et des Transmissions de Puissance, MCl Paris, France, pp. 297-302.

[4] Zhang W., Guo X. (2014). Analysis nad Modelling of Transmissions Efficiency of Vehicle Driveline. SAE 2014-01-1779, 2014. Doi: 10.4271/2014-01-1779.

[5] Changenet C., Velex P. (2006). A Model for the Prediction of Churning Losses in Geared Tranmissions - Preliminary Result, In: Journal of Mechanical Design, Vol. 129, Issue 1, 2006. doi:10.1115/1.240372

[6] Changenet C., Velex P. (2008). Housing Influence on Churning Losses in Geared Transmissions, In: Journal of Mechanical Design. Vol 130, Issue 6, 2008, doi:10.1115/1.2900714.

[7] Kahraman A., Houser D.R., Xu H. (2005). Development of a Generalized Mechanical Efficiency Prediction Methodology for Gear Pairs. Report for AGMA. Ohio State University, 2005. 